\title{
MACRO ISSUES OF MIKRO PRIMARY SCHOOL
}

\section{E Bray}

\section{Introduction}

The right to education is a universally recognised socio-economic human right and is similarly guaranteed and protected in section 29 of the Constitution. ${ }^{1}$ Owing to the nature of education and training, cultural rights ${ }^{2}$ are inextricably interwoven with the right to education.

The state as primary provider of education has undertaken to respect, protect, promote and fulfil this right, ${ }^{3}$ bearing in mind, though, that human rights are not absolute and that their nature and scope may be modified by internal qualifiers (modifiers) and their application restricted in terms of the general limitation clause whenever appropriate. In South African practice it means, for example, that a learner has a right to basic education and the right to receive such an education in a language of choice in a public school where such an education is reasonably practicable. ${ }^{4}$

It is in this context that the relevant human rights and their application by the Supreme Court of Appeal in The Western Cape Minister of Education $v$ The Governing Body of Mikro Primary School ${ }^{5}$ are scrutinised. Broadly speaking, the case dealt with the right to education in a democratic school education system and the legal status of the public school in education in South Africa.

\footnotetext{
Department of Constitutional Law, International Law and Indigenous Law, UNISA. Constitution of the Republic of South Africa, 1996 (hereafter Constitution).

Eg the right to a language and religion of choice.

Constitution, s 7. Constitution, s 29(1)-(2).

The Western Cape Minister of Education v The Governing Body of Mikro Primary School 200510 BCLR 973 (SCA). Although both the court a quo (below) and the court in casu refer to the Western Cape Minister of Education, the author prefers the correct title, ie, Member of the Executive Council responsible for education in the Western Cape Province (hereafter referred to as the MEC).
} 
This note, however, examines only two aspects of the case, namely, the right to receive education in a language of choice and the legal status of the public school to offer such education in South Africa.

\section{Background and facts}

Mikro Primary School is an Afrikaans-medium public school in Kuilsriver whose governing body had refused to accede to a request by the Western Cape Education Department to change its language policy to convert it into a parallel medium school. The head of department of Western Cape provincial education (hereafter head of department) subsequently issued a directive to the principal of the school instructing him to admit certain learners and have them taught in English. An appeal by the school to the MEC against the directive was later dismissed and resulted in the school having to admit 21 learners for instruction in English. This situation gave rise to an urgent application by the school to the Cape High Court (court a quo) for an order setting aside the directive, the decision and the plea for ancillary relief. In the a quo judgment ${ }^{6}$ the school's application succeeded and the court ordered that both the directive by the head of department and the decision by the MEC to uphold the head of department's directive be set aside. It interdicted both the head of the department and the MEC from compelling the school to admit learners otherwise than in compliance with the school's language policy and similarly restrained them from instructing or permitting departmental officials to unlawfully interfere with the school's governance and management. It ordered that the 21 learners who had been admitted to the school be placed at another suitable school(s) by the department.

Both the head of department and the MEC appealed against the whole of the judgment of the court a quo, and the parents of the 21 learners in question were joined in the proceedings as third appellants.

6 Governing Body of Mikro Primary School v Western Cape Minister of Education 20052 All SA 37 (C). 
The court (Supreme Court of Appeal) stated by way of introduction that the state has an obligation to: promote democratic transformation of the education system in line with the constitutional imperatives; combat racism and sexism and all other forms of unfair discrimination and intolerance; protect and advance diverse cultures and languages; uphold the rights of all learners, parents and educators and promote their acceptance of responsibility for the organisation, governance and funding of schools in partnership with the state. ${ }^{7}$ It also reiterated the learner's right to receive education in the official language or language of choice in a public school where such education is reasonably practicable ${ }^{8}$ the alternatives ${ }^{9}$ that would be available to realise such a right and conditions that would apply under such circumstances. ${ }^{10}$

The court alluded to the responsibility of the MEC to provide public schools for the education of learners out of funds appropriated for this purpose by the provincial legislature ${ }^{11}$ and explained the legal status of the public school as a juristic person, the governing functions of its governing body and of its principal as professional manager and direct delegate of the head of department. ${ }^{12}$ The court discussed the function of the governing body to determine the admission policy and language policy of the school subject to the Constitution and applicable national and provincial education legislation ${ }^{13}$ and then examined the power of the national Minister of Education to determine norms and standards for language policy in public schools by notice in the Government Gazette, subject to the Constitution and the Schools Act. ${ }^{14}$ The Norms and Standards for Language Policy in Public Schools allude, inter alia, to the keeping of a register of request by learners for teaching in a language medium which cannot be accommodated by schools; the determination of the language

$7 \quad$ Par 3-4.

8 S 29(2).

9 Eg single medium institutions.

10 Eg equity, practicability and the need to redress the results of past racially discriminatory laws and practices.

11 South African Schools Act 84 of 1996, s 12 - hereafter Schools Act.

12 Schools Act, s 15-16.

13 Schools Act, s 5-6.

14 GN 1701 in GG 18546 of 1997 - hereafter Norms and Standards. 
policy of a new school in accordance with the regulations and in consultation with the governing body of such a school; the fact that it is reasonably practicable to provide education in a particular language if at least 40 Grade 1 to 6 or 35 Grade 7 to 12 learners in a particular grade request it in a particular school; that the provincial department must explore ways and means of sharing scarce resources and providing alternative language maintenance programmes in schools and/or school districts which cannot be provided with and/or offer additional languages of teaching in the home language(s). ${ }^{15}$

The language policy of Mikro Primary School provides that all teaching in the school (except teaching in the learning areas English and Xhosa) takes place by medium of Afrikaans. For a number of years the department had been trying to persuade the school to change its language policy to convert it into a parallel medium school, which the school steadfastly refused to do. Within walking distance of the school was another parallel medium primary school which previously volunteered to take some of the learners, but it could not accommodate all the learners because it was full. During December 2004, after again failing to persuade the school to admit learners for instruction in English, the department finally instructed the school to admit 40 learners to the school; it offered to provide educators to ensure that effective learning and teaching takes place at the school. It also advised the school that failure to implement this directive may constitute grounds for disciplinary action. The school appealed to the MEC against the department's directive and, after a final attempt which failed to change the decision of the school, the MEC on 19 January 2005 notified the school that its appeal against the directive had been dismissed. In terms of appeal procedures set out in the Norms and Standards, in the case of such a dismissal, the decision is likewise suspended pending arbitration. The school's attorneys also indicated that in the case of such a dismissal, they would refer the matter to arbitration. The effect of the automatic suspension of the department's decision meant that the 40 learners would not be accommodated at the school and that alternative accommodation had to be found for them for the school year 2005. Although the department 
acknowledged this, departmental officials arrived on the morning of 19 January 2005 with 21 learners and their parents, instructing the chairperson of the governing body of the school that they were assisting the principal to admit the learners and to ensure that the learners were admitted and registered. ${ }^{16}$ The chairperson contended that the instructions were unlawful but the officials carried out their instructions regardless. The school then lodged an urgent application for relief, which was eventually granted by the court a quo. The court ordered, inter alia, that the directive by the department to the school to admit the learners and have them taught in English be set aside.

The MEC and the department were prohibited and restrained from compelling or attempting to compel the school or its principal to admit learners for instruction otherwise than in compliance with its language policy and applicable provisions of the Schools Act and the Norms and Standards. The court declared the department officials' conduct to be an unlawful interference with the government and professional management of the school in contravention of section 16 of the Schools Act, and prohibited and restrained them form interfering unlawfully. The MEC and department were ordered to place the 21 minor children at a suitable school(s) on a permanent basis as soon as may be reasonably practicable, and until they were so placed, they could continue to attend Mikro Primary School and receive instruction in the medium of English, provided that this situation would not continue after 2005. The department also was ordered to report to the school not later than 22 March 2005 as to what steps had been taken in this regard and, if the learners were not so placed, report monthly thereafter in writing on the progress made. The court ordered the MEC and department to bear the costs of the proceedings on a scale between attorney and client. ${ }^{17}$ 


\section{Status of a public school}

The court a quo relying on Directory Advertising Cost Cutters $v$ Minister for Posts, Telecommunications and Broadcasting ${ }^{18}$ argued that the school was not an organ of state because the legislature intended it to be independent of state or government control in the performance of its functions. ${ }^{19}$ However, this interpretation was based on the definition of organ of state in the interim Constitution which reads "organ of state includes any statutory body or functionary". In casu the court rejected this interpretation because the final Constitution now has a different and comprehensive definition of organ of state which, inter alia, determines that any institution exercising a public power or performing a public function in terms of any legislation is an organ of state. ${ }^{20}$ This means that the public school (through its governing body) is clearly an institution performing a public function in terms of the Schools Act, for example. The Constitutional Court in Independent Electoral Commission v Langeberg Municipality $^{21}$ held that although the Electoral Commission is not subject to national executive control, it constitutes an organ of state because it is a state (public) structure performing its functions in accordance with national legislation. This, however, does not mean that it falls within (or is an organ of) the national sphere of government. The Electoral Commission as an 'organ of state' therefore stands outside government and is not part of the governmental hierarchy. ${ }^{22}$

In casu, the court concluded that like the Electoral Commission, the public school is an organ of state and, in relation to its functions of determining its language and admission policy, is not subject to national or provincial executive control. In so far as the performance of those functions is concerned, it is not part of any sphere of government. The court, therefore, concurred with the court a quo and rejected the argument that the dispute with the appellants

18 Directory Advertising Cost Cutters $v$ Minister for Posts, Telecommunications and Broadcasting 19963 SA 800 (T). 
regarding the language and admission policy determined by the school, is an intergovernmental dispute as contemplated by section 41(3) of the Constitution. It also agreed with the court a quo stating that neither the provisions of the Promotion of Administrative Justice $\mathrm{Act}^{23}$ dealing with the duty to exhaust internal remedies, nor the provisions of the Norms and Standards ${ }^{24}$ was the correct option under the circumstances, stating that the cumulative effect of the factors considered by the court a quo constitute exceptional circumstances to justify the respondents from -

....any obligation they might otherwise have been under to exhaust their internal remedies. ${ }^{25}$

In coming to this conclusion the court a quo reasoned that the respondents were actually forced by appellants to launch the urgent application and this fact in itself constituted exceptional circumstances justifying the exemption referred to above. ${ }^{26}$

\section{The right to receive education in a language of choice}

The court examined the contention by the MEC and the department that in terms of section 29(2) of the Constitution everyone has the right to receive education in the official language or language of their choice in a public institution where such education is reasonably practicable. The MEC agued that it was reasonably practicable to provide education in English to the 40 learners referred to in the directive of December 2004, that the right of the governing body to determine the school's language policy was subject to the Constitution, ${ }^{27}$ the Schools Act and any provincial law, and that the governing body's language policy was therefore subordinate to the constitutional right of

23 Promotion of Administrative Justice Act 3 of 2000 (hereafter PAJA) - subs 7(2)(a) and (c).

24 Sections $\mathrm{V}, \mathrm{D}$ \& $\mathrm{E}$ - referring to arbitration.

25 Par 24.

26 Par 25-27.

27 Eg s 6(2). 
the learners in question. ${ }^{28}$ The court's counter argument was that the right to receive education in the official language of choice where it is reasonably practicable, does not mean that this right extends to each and every public educational institution where this was reasonably practicable, as the MEC and the department contended. The right is a right against the state, and the state has to give the best possible effect to this right from various reasonable educational alternatives available to it. One of the alternatives it must consider in ensuring effective implementation of this right is by providing single medium institutions. So the right exists to receive such education where reasonably practicable, but not to receive it at each and every educational institution subject to it being reasonably practicable. ${ }^{29}$ The learners in question have a right to receive such education in a public school provided by the state if reasonably practicable. However, even if it was reasonably practicable to provide such education at Mikro Primary School, the learners did not have a constitutional right to receive education in English at the school. ${ }^{30}$ Except in the case of a new school, neither the Norms and Standards nor the Schools Act or any provincial law, confer any power on the national Minister or the department to determine the language or the admission policy of a public school. The Norms and Standards also do not provide a mechanism for the alteration of the language policy of a public school, because it only authorises the Minister to determine norms and standards for language policy in the public school. Therefore, the Minister does not him/herself determine the policy of a particular school, nor does it authorises him/her to authorise any other person to do so. ${ }^{31}$ Furthermore, the quotas of learners prescribed in the Norms and Standards seem to be a guideline formulated by the Minister as to when the state would consider the constitutional right to receive education in a particular official language at a public educational institution to have been established. Neither the Schools Act nor the Norms and Standards thus purport to provide that in the event of it being practicable to provide education in a particular language at a particular school that children who wish to be educated in that language are 
automatically eligible for admission to that school for instruction in that language. ${ }^{32}$

The court held that the school's language policy and admission policy were not contrary to any provision of the Constitution, the Schools Act, the Western Cape Provincial School Education Act ${ }^{33}$ or the Norms and Standards. ${ }^{34}$ If it was reasonably practicable to educate the learners at such a school and the school unreasonably refused to change its language policy, the MEC and department would have other remedies to deal with such a case. The administrative action exercised in this regard would be subject to review ${ }^{35}$ since such an unreasonable decision could be reviewed in terms of section 6(2)(h) of PAJA. The head of the department may withdraw on reasonable grounds a function which the governing body has failed or ceased to perform. ${ }^{36}$ This power of withdrawal extends to functions allocated in both section 20 and 21 of the Schools Act, which means that any function of the governing body may be withdrawn in terms of section $22 .^{37}$ Although the MEC and the department have a remedy to deal with such a case, they failed to do so. The action by the MEC and the department substituting a governmental admission policy for that of the school, was therefore unlawful. Even if the school's language and admission policy were invalid, the department did not in terms of the Schools Act have the power to determine a language or admission policy for the school. ${ }^{38}$

\section{$5 \quad$ General observations}

This judgment made a positive contribution to education law in South Africa, particularly in relation to the interpretation and application of the right to receive education in the language of choice and the legal status of the public school

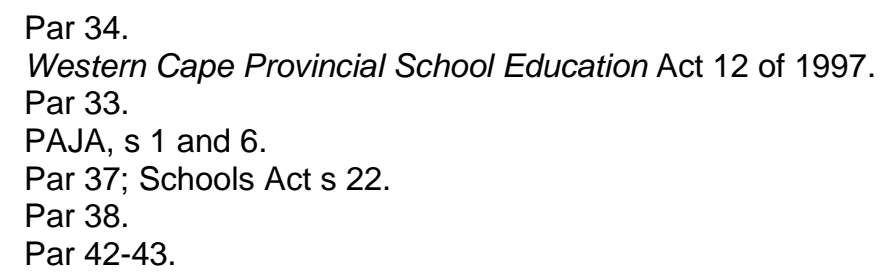


(and its governing body). In the light of the preceding discussion, the following general observations are made.

The right to receive education in a language of choice

This case dealt with rights in education, specifically the right to receive education in the language of choice at a public education institution. The right to education is an entrenched and justiciable fundamental right which the state has undertaken to respect, protect, promote and fulfil, inter alia by promulgating legislation to give effect to it, providing the public education administration with powers to implement this right and tasking the courts (judiciary) in their role as administrators of justice to administer justice impartially and without fear, favour or prejudice when this right has been encroached upon unfairly and unreasonably. ${ }^{39}$

It is a complex cross-cutting right, but also a qualified right. It deals essentially with education, but also with matters relevant (and indispensable) to education, such as, equality in education, ${ }^{40}$ the right to choose a language of choice for instruction $^{41}$ and the type of education. ${ }^{42}$ It thus cannot be interpreted and applied in isolation, but is supported (and reinforced) by other fundamental rights such as the right to equality and the right to freedom of language, culture and religion. ${ }^{43}$ Ultimately, the right to education concerns children in particular ${ }^{44}$ and this makes a reference to children's rights as important in determining the scope and application of this right, particularly the provision that in all matters concerning the child, the bests interests of the child are of paramount importance. ${ }^{45}$ The nature and scope of the right to education is also qualified by a number of internal qualifiers (modifiers) embedded in it, for example: the right

Constitution, s 165.

Eg prohibition against racial discrimination and redress of past racial discrimination.

$\mathrm{Eg}$ an official language or other language of choice.

Eg public or private education.

Eg s 8, 15 and 30.

le persons under the age of 18 years.

S 28(2). 
does not encompass all education, but only basic education, including basic adult education. ${ }^{46}$

Section 29(2) provides that everyone has the right to receive education in the official language or languages of their choice in public educational institutions where that education is reasonably practicable. This is an independent right ${ }^{47}$ and is reinforced by the equality right and the other cultural freedoms. ${ }^{48}$ Education through mother-tongue instruction is, therefore, an upfront right and the state must ensure effective access to and implementation of it. ${ }^{49}$ This right is also internationally recognised as giving effect to the right to cultural freedom and equality of treatment in the education of a person. ${ }^{50}$ To ensure effective access to and implementation of a learner's right to education in the language of choice, the state must consider all reasonable educational alternatives. In South Africa, it is not reasonably practicable to provide such education at each and every public educational institution, although most learners usually do get admitted in double medium schools where one of the languages of instruction is their language of choice. This means that such schools could accommodate the learners, provided other requirements are in place. ${ }^{51}$ The Norms and Standards drafted by the national Minister of Education provide guidelines in this regard, referring to required numbers of learners for specific grades requiring such education, and also indicate that properly qualified educators and appropriate accommodation and facilities must be available before instruction in the required language could be regarded as reasonably practicable at a specific public school.

46 Carpenter 1995 SAPR/PL 260-263.

47 le an upfront right such as the right in subs (1), and not subject to it.

$48 \mathrm{Eg}$ the right to equality of language and the freedom to choose your own language $-\mathrm{s} 9$ and 30 respectively - as well as the freedom of language within a specific language/cultural community, such as a school - s 31. See Malherbe 1997 TSAR 58, 6466.

49 Malherbe 1997 TSAR 95-98; Liebenberg Interpreting Socio-economic Rights 33.17-25.

50 UN Convention on the Rights of the Child 1991 a 28 and 29; African (Banjul) Charter on Human and Peoples' Rights 1981 a 17.

51 Eg the school must be able to provide proper place for the additional learners - not be overcrowded - and there must be properly qualified educators and proper facilities to accommodate them. 
The reasonable educational alternatives that the state must consider in giving effect to and implement this right, include a consideration of single medium institutions on condition that other additional factors are taken into account, such as equity, practicability and the need to redress past racially discriminatory laws and practices. $^{52}$ In a multicultural democratic society in which the state promotes a democratic education system based on the values of equality, dignity and human freedom, it is important to set these additional requirements where the only other reasonable educational option is a single medium public institution: this is to prevent such a school from, inter alia, protecting and promoting a single cultural freedom above other freedoms, promoting unfair discrimination ${ }^{53}$ under the guise of protecting and promoting cultural freedoms, ${ }^{54}$ or, simply excluding learners because their standard of English/Afrikaans is substandard. ${ }^{55}$ All this boils down to not addressing or redressing past racial equalities, denying learners the opportunity to achieve the full enjoyment of their human rights, especially the right to a language of choice $^{56}$ in education.

In sum, the right to freedom of choice in the language of instruction in a public school is a fundamental right and the state must ensure that this right is realised in practice. However, there is no right to receive such an education at a single medium public school (for example an Afrikaans medium public school), and neither at a specific single medium public school (for example Mikro Primary School). Nevertheless, once a single medium school proves to be a reasonably practicable (alternative) option, ${ }^{57}$ the courts will have to determine in each case of alleged unfair discrimination whether such alleged unfair discrimination is in fact unfair or 'fair' discrimination, taking into account the factors prescribed in section 36 of the Bill of Rights. ${ }^{58}$ In casu the court did not have to apply the limitation clause because the case presented by Mikro

52 Constitution, s 29(2).

53 Eg on on the basis of race, colour or sex.

54 See Matukane v Laerskool Potgietersrus 19963 SA 223(T).

55 Eg in applications to previously C-Model English/Afrikaans medium schools.

56 Eg mother-tongue instruction.

57 Eg taking into account the guidelines in the Norms and Standards and other factors mentioned in the context of single medium schools.

58 See Harksen v Lane 199711 BCLR 1489 (CC). 
Primary School was decisive and keeping the learners in the school would in any case not have served their best interests. ${ }^{59}$ Consequently, the factor counting against the state ${ }^{60}$ was so strong that the question regarding unfair discrimination suffered here by the learners in question did not feature strongly and therefore was not considered by the court. Sadly, though, this is just another example and reminder of the tardiness (and incompetence) of the state to properly fulfil its obligations in terms of education rights. ${ }^{61}$

The legal status of a public school in education in South Africa

In terms of the constitutional imperatives of power-sharing, education is a functional area shared (i.e. concurrently) by the national and provincial spheres of government. The national government is, for example, responsible for education legislation that applies nationally ${ }^{62}$ and consequently deals with national norms, standards and qualifications for education. ${ }^{63}$ The provincial sphere of government is in terms of the Constitution in charge of school education and all public schools therefore are regarded as provincial public schools with the provincial government administering schools in the province according to the needs and priorities of the particular province, but subject to overall national standards. ${ }^{64}$ In this relationship of co-operation and sharing of powers ${ }^{65}$ the national and provincial governments must work in a spirit of trust and partnership and as 'equal' partners: resources must be shared, capacity must be built to provide better education services to the public and conflict must

59 "Best interests" used here in the sense of its paramount importance, but not overriding, unlimited importance - par 48. See Friedman and Pantazis Children's Rights 33-35.

60 Viz neglecting to provide facilities to realise this fundamental right to education in a language of choice at a public education institution where reasonably practicable.

61 See Minister of Education v Harris 200111 BCLR 1157 (CC) on school-going age and admission; Maritzburg College v Dlamini Unreported 27 May 2003 Case Number 2089/2004 on departmental incompetence regarding learner expulsion, discussed by Carnelley 2005 SAPR/PL 128-153, and its slow pace in addressing socio-economic rights in general (see Larbi-Odam v MEC for Education (North-West Province) 199612 BCLR 1612 (BSC); Soobramoney v Minister of Health (Kwa Zulu-Natal) 19981 SA 765 (CC); Grootboom v Oostenberg Municipality and Others 20003 BCLR 277 (C)).

62 To educational institutions at all levels of education throughout the country.

63 Eg the National Education Policy Act 27 of 1996; the Schools Act.

64 S 40-41, read with sch 4.

65 Constitution, ch 3. 
be avoided and resolved in the prescribed manner. ${ }^{66}$ In line with the constitutional prescriptions, the government spheres responsible for school education have to transform the education system and develop a democratic and uniform school education system in line with the needs of a newly developing and democratic South African nation. To this effect, government has decentralised school education and vested provincial public schools with autonomous self-governing powers - all individual public schools are juristic persons and in charge of their own school governance. ${ }^{67}$ In this spirit, an education partnership has been initiated between schools and the state (in casu provincial government), with the understanding that both parties undertake to fulfil their respective powers and obligations for the promotion of democratic school education and, in essence, involve all stakeholders in education $^{68}$ through the practising of democratic values and norms in the governance (and management) of public schools. ${ }^{69}$

One of the important empowerment initiatives in this democratisation process, is to capacitate by means of statutory provisions the public school (a juristic person) via its functionary (the representative governing body) to, inter alia, adopt certain legal documents for the school, for example, a constitution, the code of conduct for the learners as well as specific policy documents, including a language policy and admission policy for the school. ${ }^{70}$ These documents must be in line with relevant constitutional provisions and other national and provincial school education legislation. ${ }^{71}$

All public schools are also 'organs of state' in the sense that they are functionaries/institutions exercising public powers and performing public functions in terms of legislation. ${ }^{72}$ In this public context they perform typical administrative actions in the day-to-day management and governance of the

66 Bray 2002 JCRDL 520-523.

67 Schools Act, s 15-16.

68 le parents, educators, learners and the government.

69 Schools Act, preamble, s 23 and 28.

70 Schools Act, s 6.

71 Eg Schools Act, Norms and Standards, and Western Cape School Education Act.

72 Constitution, s 239(b)(ii); Mdumbe 2005 SAPR/PL 22-24. 
school $^{73}$ and their 'domestic' laws ${ }^{74}$ and the conduct of their functionaries ${ }^{75}$ are subject to, and must ultimately comply with relevant constitutional prescriptions. ${ }^{76}$ To fulfil its 'public domain' education functions properly, the governing body governs the school as an autonomous (self-governing) institution and without undue influence by the government. However, in governing the school (as an 'organ of state') it must adhere to the basic democratic values and principles governing the public administration, ${ }^{77}$ which include principles such as transparency, representivity and accountability.

It is trite that the public school, as an organ of state, does not form part of the spheres of government or organs of government working within these spheres, but that the public school exercises public powers and performs public functions in the broader public education domain. However, the stance by the court a quo that the governing body (which should read the school - the legal person) is acting free of national and provincial executive control when determining its language and admission policy, is stretching it too far: these public functionaries always will be subject to the Constitution ${ }^{78}$ from which their powers and functions originate. Although the court in casu admitted that this reasoning by the court a quo was incorrect, it did not substantiate its stance and also failed to reflect it in its final judgment on this point.

In terms of legislation, the public school functions as a juristic person within the public education system. Its governing body is vested with statutory powers/functions and may only exercise those powers and functions allocated to it in terms of such legislation. These powers and functions are exercised by the governing body in the name of the school and in the best interests of the school and all its learners. ${ }^{79}$ The school remains subject to overall control by the national education government in that it has to comply with national norms

73 PAJA, s 1.

74 le constitution, policy documents and code of conduct for learners.

75 Eg educators and governing body.

76 Constitution, eg s 2, 8 and 237.

77 Constitution, s 195(1) and (2).

78 Eg s 195, 33 and 39 - the interpretation clause.

79 Schools Act, s 16, 18A and 20. 
and standards that are binding on all public schools in the country, ${ }^{80}$ as well as provincial norms and standards of a specific province. ${ }^{81}$ With regard to school governance matters, the public school can at best be described as an autonomous (self-governing) entity, in line with the principle of decentralisation of powers, and in charge of its own governance as statutorily provided for.

As mentioned before, all 'organs of state' functioning within or outside the spheres of government, are also bound by the provisions of section 195 of the Constitution, primarily to ensure that they comply with the provisions of the Constitution regarding the rendering of public services. Therefore, despite the fact that the term 'organ of state' has been extended in terms of the Constitution and that the dispute between the school and the MEC (and department) is not an intergovernmental dispute, Mikro Primary School (via its governing body) does not function independently of state or government control in the performance of its functions - be it governance or management functions. In fact, the principal and educators serving on the governing body (as governors) also represent government interest (professional education and management) in the context of school governance. It is a pity that the court did not rectify and address this point; it simply explained the concept 'organ of state' in terms of the Constitution, without examining the legal consequences of exercising (or failing to exercise) a public education power and performing (or failing to perform) a public education function in the South African public education system.

Finally, the crucial issue of this case is the fact that neither the MEC nor the department had the power to usurp the power of Mikro Primary School to adopt its own language and admission policy. The MEC and department had other legal ways to deal with a recalcitrant governing body, as determined by the Schools Act. Nevertheless, to what extent the government would use its overall powers of control to bring these public schools back into its 'controlling' fold is uncertain. One way of achieving this is to change legislation - and the latest

80 Eg the Schools Act.

81 Eg the Western Cape Provincial School Education Act. 
amendments to school legislation provides manifest proof of this authoritative (possibly authoritarian) trend where, slowly but surely, government is chipping away at the autonomous self-governing powers and functions of public schools. ${ }^{82}$ This surely encroaches upon the legal personality of a public school and, ultimately, negates the spirit and purport of constitutional transformation, democratic education and participation of all stakeholders in education in South Africa.

82 Eg in the Schools Act (s 20) where the governing body's power to recommend and appoint educators has been restricted; general media statements by the ministry proposing a stronger position for the principal on the governing body; and the Education Law Amendment Act 24 of 2005 which is causing confusion and alarm about the role of the governing body and head of department in learner suspensions and expulsions. 


\section{Bibliography}

Boshoff and Morkel Education Law and Policy Handbook

Boshoff E and Morkel P Juta's Education Law and Policy Handbook $3^{\text {rd }}$ rev (Juta Cape Town 2002)

Bray 2002 JCRDL 514-531

Bray E "The constitutional concept of co-operative government and its application in education" 2002 Journal of Contemporary Roman-Dutch Law 514-531

Bray Human Rights in Education

Bray W Human Rights in Education $2^{\text {nd }}$ ed (CELP Pretoria 2004)

Carnelley 2005 SAPR/PL 128-153

Carnelley M "The decision-making power of the head of the Department of Education to expel learners" 2005 South African Publiek Reg / Public Law 128-153

Carpenter 1995 SAPR/PL 260-282

Carpenter C "Internal modifiers and other qualifications in bills of rights Some problems of interpretation" 1995 South African Publiek Reg / Public Law 260-282

De Waal and Currie Bill of Rights Handbook

De Waal J and Currie I The Bill of Rights Handbook (Juta Lansdowne 2005) 636

Friedman and Pantazis Children's Rights

Friedman A and Pantazis A "Children's Rights" in Chaskalson $\mathrm{M}$ et al Constitutional Law in South Africa $2^{\text {nd }}$ ed (Juta Lansdowne 2004) 47.1 
Liebenberg Interpreting Socio-economic Rights

Liebenberg S "Interpreting Socio-economic Rights" in Chaskalson M et al Constitutional Law in South Africa $2^{\text {nd }}$ ed (Juta Lansdowne 2004) 33.2

Malherbe 1997 TSAR 85-99

Malherbe EFJ "Reflections on the background and contents of the education clause in the South African Bill of Rights" 1997 TSAR 85-99

Malherbe Education clause in the South African Bill of Rights Malherbe EFJ "The education clause in the South African Bill of Rights: Background and contents" in De Groof $\mathrm{J}$ and Malherbe EFJ (eds) Human Rights in South African Education (Acco Leuven 1997) 53-67

Malherbe Perspectives in Education 9-28

Malherbe $\mathrm{R}$ "The constitutional framework for pursuing equal opportunities in education" 2004 Perspectives in Education 9-28

Mdumbe 2005 SAPR/PL 1-28

Mdumbe $F$ "The meaning of 'organ of state' in the South African

Constitution" 2005 South African Publiek Reg / Public Law 1-28

\section{Register of legislation}

Constitution of the Republic of South Africa 1996

Education Law Amendment Act 24 of 2005

Government Gazette no 18546 of 19 December 1997

National Education Policy Act 27 of 1996

Promotion of Administrative Justice Act 3 of 2000

South African Schools Act 84 of 1996

Western Cape Provincial School Education Act 12 of 1997

\section{Register of court cases}

Directory Advertising Cost Cutters v Minister for Posts, Telecommunications and Broadcasting 19963 SA 800 (T) 
Governing Body of Mikro Primary School v Western Cape Minister of Education 20052 All SA 37 (C)

Grootboom v Oostenberg Municipality and Others 20003 BCLR 277 (C)

Harksen v Lane NO 199711 BCLR 1489 (CC)

Independent Electoral Commission v Langeberg Municipality 20013 SA 925

(CC)

Larbi-Odam v MEC for Education (North-West Province) 199612 BCLR 1612

(BSC)

Matukane v Laerskool Potgietersrus 19963 SA 223 (T)

Maritzburg College v Dlamini NO Unreported 27 May 2003 Case Number 2089/2004

Minister of Education v Harris 200111 BCLR 1157 (CC)

Soobramoney v Minister of Health (Kwa Zulu-Natal) 19981 SA 765 (CC)

\section{Charters and conventions}

African (Banjul) Charter on Human and Peoples' Rights 1981

United Nations Convention on the Rights of the Child 1991

\section{List of abbreviations}

$\begin{array}{ll}\text { a } & \text { article(s) } \\ \text { ch } & \text { chapter(s) } \\ \text { MEC } & \text { Member of the Executive Council } \\ \text { par } & \text { paragraph(s) } \\ \text { s } & \text { section(s) } \\ \text { sch } & \text { schedule(s) } \\ \text { subs } & \text { subsection(s) } \\ \text { PAJA } & \text { Promotion of Administrative Justice Act } \\ \text { UN } & \text { United Nations }\end{array}$

